УДК 353.103

O. I. Васильєва,

д. держ. упр., професор, професор кафедри публічного управління та публічної служби,

Начіональна академіл державного управління при Президентові України

ORCID ID: 0000-0003-1812-4557

A. О. Рибка,

аспірант кафедри публічного управління та публічної служби, Начіональна академіл

державного управління при Президентові Украӥни

ORCID ID: 0000-0001-8599-8268

DOI: $10.32702 / 2306-6814.2021 .4 .93$

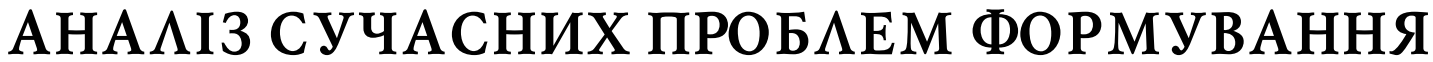

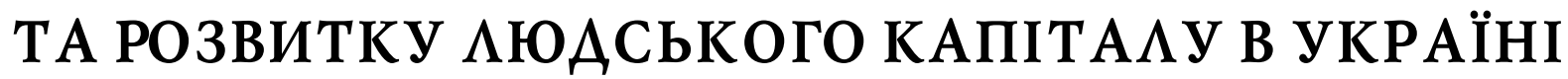

\author{
O. Vasylieva, \\ Doctor of Sciences in Public Administration, Professor, Professor of the Department of Public Administration \\ and Public Service, National Academy for Public Administration under the President of Ukraine, Ukraine \\ A. Rybka, \\ Postgraduate student of the Department of Public Administration and Public Service, \\ National Academy for Public Administration under the President of Ukraine
}

\section{ANALYSIS OF MODERN PROBLEMS OF FORMATION AND DEVELOPMENT OF HUMAN} CAPITAL IN UKRAINE

Устаттідосліджується сучасний стан розвиткулюдського капіталу в Україні. Розкрита роль людського капіталу у світовій економічній практиці як найціннішого виробничий ресурсу, що постійно оновлюється, вдосконалюється, адже саме він є запорукою та основною силою інноваційного та соціально-економічного прогресу. Тому саме людський капітал є домінантою можливого стабільного зростання економіки України. Доведено, що від якості людського капіталузалежать не лише темпи поширення нових знань у суспільстві, а й темпи розробок і впровадження нової техніки та технологій, виробництво кінцевих продуктів споживання тощо.

Проаналізовано проблеми інвестування улюдський капітал, доведена необхідність поліпшення інституційної бази повернення та розвитку національного людського капіталу, на цій основі розроблено пропозиції та рекомендацій щодо напрямів стимулювання розвитку людського капіталу. Доведено, що основним негативним фактором, що впливає на розвиток людського капіталу в Україні є недосконалість національної інституційної бази.

Устатті, такожпроаналізовано проблеми формування та використаннянаціональноголюдського капіталута визначенонайбільшдієві напрями, інструментитаметоди соціальної політики, длязабезпеченняефективного функціонування та розвитку людського капіталу в Україні. Запропоновано заходи для створення нових можливостей для формування, залучення, збереження та розвиткулюдського капіталу в Україні.

The article analyzes the current state of human capital development in Ukraine. Today, in world's economic practice the human capital is considered as the most valuable, continuously updated, improved resource, which appears the key to and the main strength of innovation and socio-economic progress.

In recent years, Ukraine has been carrying out intensive and unprecedented reforms, but in order to accelerate National institutional reforms, transformation of the state, technological upgrading of productions, as well as transformations of the economy, the country needs a high level and quality of accumulated human capital, therefore, the human capital is the dominant for the stable growth of Ukraine's economy. The quality of human capital depends not only on the pace of dissemination of new knowledge in society, but also on the pace of development and introduction of new technologies.

Taking into account that in the system of world rankings according to indicators of competitiveness, innovation and human capital, Ukraine lags behind the developed countries according to many parameters; forthe transition of the domestic economy to the innovative model of development, the problems of improving the mechanism of investing in human's capital, improving the institutional base for the development of human capital, the definition of its state and dynamics in the coming years and on this basis further suggestions and recommendations development towards the evolution of innovative human.

In domestic economic literature the theory of human capital became more important only in last two decades. However, the worldexperience of formation and development of human capital remains insufficiently researched. 
The urgency of the problem of formation and accumulation of national human capital at the present stage, requires furtherstudy.

The purposes of this article are: to study the problems of human capital formation in Ukraine, to identify the most effective directions, tools and methods of social policy that ensure the effective functioning and development of human capital as a productive factor of national development, to analyze the national experience of human capital development

Negative signs of human capital development in Ukraine are the imperfection of national legislation on human capital development strategy, reduction of the number of educational and medical institutions and reduction of the quality of their services, as well as the inability of trade unions to raise the price of individual human capital. Therefore, there is a need to form a new institutional framework that should create favorable conditions for the development of domestic human capital.

To create new opportunities for the formation, attraction, preservation and development of human capital in Ukraine, at the state level it is necessary to develop effective measures for the development of national human capital, namely: programs to support young professionals, small business development, to reduce labor migration abroad, develop mechanisms to empower people, promote the development of innovative industries and improve the skills of employees on an ongoing basis, increase funding for health and education systems, in order to return human resources from abroad it should be created favorable conditions for return, implement a number of programs to repatriation and return of Ukrainian labor migrants, etc.

Prospects for the further research are to identify ways and strategies for the formation of a highly skilled workforce, reducing the outflow of specialists, i.e. the creation of quality human capital in the post-crisis period. The key task facing Ukraine is the transition from mainly export-raw to investment-innovative type of economic development, increasing competitive Ukrainian human capital based on the realization of national advantages in science, education and high technologies.

КлючоВі слоВа: національний людський капітал, формуВання національного людського капіталу, економічне зростання, інновачії, ефектиВність, прогрес.

Key words: national human capital, formation of national human capital, economic growth, innovation, efficiency, progress.

\section{ПОСТАНОВКА ПРОБАЕМИ ТА ЇÏ ЗВ'ЯЗОК ІЗ ВАЖАИВИМИ НАУКОВИМИ ЧИ ПРАКТИЧНИМИ ЗАВААННЯМИ}

У вітчизняній науковій літературі теорії людського капіталу почали надавати важливішого значення тільки упродовж останніх двох десятиріч, але така економічна категорія, як "людський капітал" вже давно перетворилась $з$ теоретичних розробок на практичну основу зростання та розвитку сучасної економіки в умовах глобалізації. Актуальність проблеми формування і накопичення національного людського капіталу в країні на сучасному етапі, вимагає подальшого його дослідження.

Виділення невирішених раніше частин загальної проблеми, котрим присвячується стаття. 3 огляду на те, що в системі світових рейтингів за показниками конкурентоспроможності, інновацій і людського капіталу Україна відстає від розвинених країн світу за багатьма соціально-економічними параметрами, з метою поліпшення ситуації в цій сфрері, необхідно визначити основн проблеми створення якісного людського капіталу в посткризисний період та дослідити сучасний стан фрормування людського капіталу в країні.

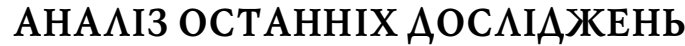

Серед економістів, які займалися дослідженням окремих питань формування і розвитку людського капіталу України, слід назвати В. Антонюк, В. Близнюка, О. Бородіну, В. Гейця, Н. Голікову, О. Головінова, О. Грішнову, М. Долішнього, І. Журавльову, С. Злупка, С. Клименко, В. Куценко, Е. Лібанову, Г. Назарову, К. Павлюка, Ж. Поплавську, О. Стефанишина, С. Трубича, А. Чухна та інших вітчизняних учених-економістів. Проте стан сучасних проблем формування та розвитку люд- ського капіталу в України потребує подальшого аналізу.

\section{META CTATTI}

Метою статті $є$ :

- дослідити проблеми фрормування та використання людського капіталу в Україні;

- визначити найбільш дієві напрями, інструменти та методи соціальної політики, що забезпечують ефективне функціонування та розвиток людського капіталу як продуктивного чинника національного розвитку;

- дослідити вплив інвестицій на людський капітал;

- провести аналіз національного досвіду розвитку людського капіталу.

\section{ВИК ААА ОСНОВНОГО МАТЕРІААУ}

Проблеми ефективного використання людського капіталу у вітчизняній науці досліджені ще недостатньо. Учені, зазвичай, приділяють найбільшу увагу такому питанню, як інвестиції в освіту і віддачу від них, залишаючи поза увагою механізм ціноутворення на індивідуальний людський капітал, який впливає на підвищення добробуту населення, залежність формування людського капіталу інноваційного типу від збільшення державного фрінансування науки і використання його як основного активу економічного зростання.

У структурі людського капіталу необхідно виокремити знання та здібності людини, стан її здоров'я, досвід, навички працівника, а також мотивацію праці. Одночасно важливо розглянути роль людського капіталу у розвитку суспільства і економіки через аналіз таких функцій, як відновлення, накопичення та стимулювання розвитку національного людського капіталу. 
Згідно з опублікованим Рейтингом Країн Світу 2019 (Індексом глобальної конкурентоспроможності), що розраховується фрахівцями Всесвітнього економічного фроруму, Індекс глобальної конкурентоспроможності формується з 12 контрольних показників, до складу яких входять більш ніж 100 змінних, а саме: інституції, інфраструктура, макроекономічне середовище, охорона здоров'я та початкова освіта, вища освіта і професійна підготовка, ефективність ринку товарів, ефективність ринку праці, розвиток фрінансового ринку, технологічна готовність; розмір ринку, відповідність бізнесу сучасним вимогам та інновації. Україна погіршила свої позиції у 4 з 12 основних показників: інфрраструктура, вища освіта і профресійна підготовка, ефективність ринку праці та інновації, що $є$ негативною тенденцією. Найбільше позицій в рейтингу Україна втратила за оцінкою ефективності ринку праці за такими показниками: - визначення заробітної плати - 126 позиція в рейтингу (мінус 45 пунктів у порівнянні з попереднім роком); 89 - здатність країни утримувати таланти 129 позиція в рейтингу серед країн світу (мінус 13 пунктів у порівнянні з попереднім роком) [1].

Низькі позиції України у рейтингу, пов'язані з формуванням людського капіталу, спричинені саме недостатньою технологічною готовністю, що складає 3,45 пунктів порівняно з 4,6-6,42 пунктами в ЄС. У той же час за індексами ефективності ринку праці та вищої освіти і професійної підготовки Україна наближається до рівня країн ЄС. Згідно зі стадіями економічного розвитку національних економік, що використовуються для порівняння конкурентоспроможності країн у Звіті з глобальної конкурентоспроможності 2018 [2].

Всесвітнім економічним форумом визначено, що Україна відноситься до країн, розвиток яких зумовлюється ефрективністю (efficiency driven), де зростання економіки залежить від інвестицій, а конкурентоздатність досягається через використання світових технологій у власному внутрішньому виробництві. Сьогодні для підвищення інвестиційної привабливості та залучення новітніх технологій, з метою подальшого переходу до групи країн, розвиток яких керується інноваціями (innovation driven) необхідні зусилля держави у розвитку власної інфрраструктури. Також Всесвітнім економічним форумом розраховується Індекс людського капіталу, що характеризує країни за рівнем його фрормування та використання. За цим показником Україна наближається до рівня країн ЄС, таке явище у Звіті з людського капіталу пояснюється високим рівнем освіти населення та успадкованим потенціалом наукової діяльності та суперечить найнижчим показникам ВВП на душу населення в регіоні. У системі міжнародних координат за рівнем людського капіталу в 2017 р. Україна перебувала на 24-му місці серед 130 країн світу. Ї̈̈ рейтинги зачастковими індексами варіюють від 45-ї позиції у світі за доступністю та якістю освіти до 96-ї за показниками сприятливого середовища. Разом з тим, станом на 2017 р. показники ефективності використання людського капіталу в країні були найнижчими та становили 0,59 , запропонований показник розраховано, як співвідношення ВВП на душу населення до заробітної плати, і демонструє скільки одиниць ВВП приносить кожна одиниця витрат на оплату праці носіїв людського капіталу [3].

Зрозуміло, що побудова інноваційної моделі ринкової економіки в Україні, великою мірою залежить від людського капіталу, який водночас виступає важливою складовою національного багатства. Вумовах загострення конкуренції країн світу, коли відбувається переосмислення ролі людини як ключового чинника підвищення конкурентних переваг національної економіки, творчі здібності людини, на відміну від інших видів ресурсів, виступають ядром інноваційного потенціалу особистості й мають невичерпний характер. Головними відмінностями творчої людини є: нестандартний підхід до вирішення проблем, креативність і масштабність мислення, цілеспрямованість, швидке реагування на реалізацію нових ідей тощо. Проте останніми роками в Україні відстежується певна негативна тенденція зменшення частини людського капіталу у загальній структурі національного багатства.

Але, навіть попри те, що розвиток людського капіталу визначено одним з пріоритетів Цілей сталого розвитку України на період до 2030 року та помітне збільшення видатків державного бюджету України на соціальний захист та соціальне забезпечення, з 218 млрд грн у 2019 році до 322 млрд грн у 2020 році, аналіз державних видатків у соціальну сферу все ж таки свідчить про недостатній обсяг інвестування в людський капітал України [4]. Відтак результативність інвестицій у людський капітал визначається тим, наскільки використовуються здобуті індивідом знання в економічній діяльності. Величини обчислених коефіцієнтів кореляції між кількістю випускників освітніх закладів і продуктивністю праці в Україні свідчить про їх тісний зв'язок [5].

Сьогодні Уряд України пропонує впровадити базовий соціальний стандарт нижче розміру, ніж було пораховано згідно з чинною на сьогодні методикою його показників, це також не враховує знецінення грошових доходів та заощаджень громадян внаслідок високої цінової інфляції, девальвації національної валюти і зумовить зниження купівельної спроможності населення (й відповідно фрормування ВВП), погіршення рівня його життя та соціальної захищеності, створить передумови подальшого зубожіння, особливо найбільш уразливих верств населення, зокрема, тих, для кого пенсії, інші види соціальних виплат та допомоги $€$ основним, зазвичай єдиним, джерелом існування [6].

Згідно з статті 48 Конституції України, кожен громадянин України має право на достатній життєвий рівень для себе і своєї сім'ї, що включає достатнє харчування, одяг, житло. Це положення Основного Закону випливає із припису статті 25 Загальної декларації прав людини щодо забезпечення високої якості життя на засадах соціальної справедливості, досягнення гідного життєвого рівня [7].

Таким чином, виявляється, що ресурс вітчизняного людського капіталу неефективно використовується в економіці України, з таких причин: виробництво експлуатує людський капітал, ще створений за часів радянської системи, спостерігається відсутність соціальної відповідальності бізнесу, неузгодженість між підготовкою навчальними закладами фахівців певних спеціальностей $\mathrm{i}$ нагальною потребою національної економіки та занадто низькі ціни на людський капітал. Сьогодні людський капітал - головна цінність громадського суспільства, а також базовий фактор економічного зростання держави. Інноваційна модель економічного розвитку, основними рушійними силами якого все більше стають нові знання та технології, творчий та інтелектуальний потенціал людини і суспільства, робить людський капітал стратегічним 
ресурсом конкурентної боротьби. Проблема фрормування та збереження людського капіталу має велике значення як для самої людини, так і для будь-яких підприємств та держави загалом [8]. Коли йдеться про капітал, то маються на увазі певні активи - обладнання, споруди, комунікації, які володіють двома властивостями: вони $є$ результатом інвестування та генерують дохід протягом певного проміжку часу. Так, і людський капітал створюється шляхом інвестицій в охорону здоров'я та початкову освіту та згодом окупається у вигляді висококваліфрікованої праці та її достойної оплати.

Цілеспрямовані інвестиції є головним інструментом фрормування та розвитку людського капіталу. Їх можна розділити на прямі, бо інвестування в професійну освіту, наукові розробки, підготовку кадрів, здоров'я, допомогу при народженні та вихованні дітей, інші державні соціальні програми та непрямі - витрати на поліпшення відносин у колективі, створення робочої атмосфери, поліпшення культури праці, виховання тощо. Накопичення людського капіталу приносить суспільству чималі економічні вигоди, сприяє досягненню більшого порозуміння у суспільстві, поширенню інновацій, підвищенню культури, інтелекту індивідів та ін. Людський капітал відчуває велику потребу глибоко аналізувати довгострокові інвестиції у людину, у людський капітал, оскільки це має велике практичне значення. Досвід переконливо доводить, що інвестиції в науку та освіту за своїми наслідками $є$ продуктивними капіталовкладеннями, оскільки дають певний економічний ефект [9, с. 878].

Міграція є значимим фактором, що впливає на фрормування та розвиток людського капіталу. Україна має величезний людський потенціал, але в країні вже тривалий час спостерігається стабільний відтік висококваліфрікованих фрахівців, як правило, з їх інноваційними напрацюваннями (англ. brain drain - "відтік мізків"). Сьогодні "відтік" молодих і висококваліфікованих фрахівців стає потенційним викликом для України. На превеликий жаль, статистика Державної служби статистики України не відображає фрактичний масштаб "відтоку мізків" за кордон. Останніми роками переїзд випускників українських шкіл на навчання закордон, найчастіше до країн ЄC, особливо Польщі, набуває великого поширення. Офіційної статистики немає, але за приблизними підрахунками число українських студентів у ЄС складає від 60 до 70 тисяч і тільки у Польщі - понад 30 тисяч. Українці становлять більше половини всіх закордонних студентів цієї країни. За результатами проведених опитувань лише один з десяти з них планує повернутись в Україну, третина планує залишитись у Польщі, ще третина з них бажає переїхати в іншу країну ЄС. Але у Польщі напрями студентської міграції зовсім інші - це США, Велика Британія, Німеччина та Австралія. Таким чином, процес освітньої міграціє полягає у тому, що чим більш економічно розвиненою $є$ країна, то меншоює й освітня еміграція.

Деякі розвинені країни стимулюють (безкоштовне навчання, стипендії, першочергове отримання навчальних віз тощо) українських студентів на навчання у своїх університетах. Серед прикладів ті ж Польща, Ізраїль, Словаччина, Чехія, Німеччина. Українські студенти мають гарний рівень підготовки, схожий менталітет, перспективу по закінченню навчання залишитись та працювати на економіку країни. Таким чином, освітня міграції українців, негативно впливає на економіку та соціальну сореру в Україні, хоча може мати і свої позитиви (у разі повернення студентів в Україну після навчання), що зумовлює актуальність розробки дієвих заходів щодо майбутнього управління таким явищем.

Схожа ситуація виникла у багатьох східноєвропейських та північноєвропейських країн після їх приєднання до Євросоюзу, наприклад у Польщі, Болгарії, Румунії, Литві, Латвії, досвід боротьби з якою корисний для України. В країнах Східної Європи запущено урядові кампанії з метою переконання молоді повернутися з країн західної Європи. У Польщі, наприклад, для повернення співвітчизників започаткували державну програму Powroty ("Повертайтеся"), в рамкахцієї програми надається логістична допомога у знаходженні житла, роботи, отримання медичного обслуговування; у Румунії створено об'єднання підприємств та університетів, що пропонує людям, які повернулися, безкоштовне навчання і привілеї під час працевлаштування; у Латвії - надаються робочі місця у державному секторі. Індія, країна з найбільшою в світі діаспорою, була однією з перших держав, в якій відбувся зворотний процес - "приплив мізків" додому. 3 метою заохочення людей повертатися, уряд підтримує центри досліджень і розвитку, особливо у сферах технологій, охорони здоров'я та фрармацевтики [10].

Таким чином, "відтік мізків" реально та необхідно переробити у процес із зворотною дією, коли кваліфіковані фрахівці залишають країну та імміграціюу розвинені країни, а потім повертаються до неї з новими ідеями та удосконаленими навичками. Загалом, чим кращі можливості в державі, де спостерігається відтік висококваліфікованих кадрів, тим вища ймовірність повернення висококласних фахівців на батьківщину.

Транссрормаційні процеси в Україні помітно позначилися на основних елементах формування та розвитку людського капіталу. Вони, з одного боку, як стимулювали його розвиток через зростання освітнього рівня населення, так і впливали на зниження природного приросту населення, сприяли підвищенню трудової міграції, тим самим визначили тенденцію до зниження обсягу людського капіталу в країні. Це виявилося у тому, що:

1) функції працюючого капіталу перетворилися у функції робочої сили;

2) економічна криза набрала фрорми дисфункції (втрату людським капіталом зростання доданої вартості та доходу на різних рівнях: особистому, корпоративному, регіональному та національному);

3) зростала як асоціальна частка людського капіталу, так і кількість тих, хто реалізував свій ресурс за кордоном чи в тіньовій, корумпованій економіці;

4) держава не створила умов попиту на кваліфріковану працю (через відсутність кореляційного зв' язку між заробітною платою та рівнем професійної підготовки);

5) процеси державного інвестування у формування цього активу (витрати на освіту, науку, охорону здоров'я) носили деструктивний характер, що призвело до низького рівнів тривалості та якості життя населення.

Порівнюючи основні показники з відповідними даними по Україні, встановлено, що рівень соціальної орієнтованості нашої країни не є високим, однак, за показниками рівня безробіття населення, обсягу інвестицій у людський капітал та бідності Україну можна ха- 
рактеризувати як країну із середнім рівнем орієнтації економіки на соціальну сферу.

\section{ВИСНОВКИ І ПЕРСПЕКТИВИ ПОАААЬШИХ РОЗВІАОК}

Негативними ознаками розвитку людського капіталу в Україні $€$ недосконалість національної інституційної бази стосовно стратегії формування та розвитку людського капіталу. Необхідно вдосконалити національне законодавство для створення сприятливих умов у сфері формування та розвитку вітчизняного людського капіталу. Одночасно необхідно погодитись з тим, що становлення інноваційної моделі розвитку національної економіки залежить від розвитку людського капіталу інноваційного типу, формування якого, в свою чергу, залежить від соціальної орієнтованості країни. Зважаючи на сучасний достатньо невисокий рівень соціального розвитку України, неважко зрозуміти, що саме це і надалі створюватиме перешкоди для кількісного та якісного зростання національного людського капіталу.

Безперечно, людський капітал виступає найбільш цінними ресурсом сучасного суспільства, важливішим, ніж накопичене багатство чи природні ресурси. Для створення нових можливостей для формування, залучення, збереження та розвитку людського капіталу в Україні, на рівні держави необхідно розробити ефективні заходи для розвитку національного людського капіталу, а саме: програми підтримки молодих спеціалістів, розвитку малого підприємництва, для зменшення трудової міграції населення за кордон потрібно розробити механізми активізації потенціалу людей, сприяти розвитку інноваційних галузей та підвищенню кваліфікації працівників на постійній основі, підвищити фрінансування витрат на системи охорони здоров'я та освіти, з метою повернення людських ресурсів із-за кордону варто створити сприятливі умови для повернення та запровадити низку програм по репатріації та поверненню українських трудових мігрантів тощо.

Перспективами подальших розвідок є визначення шляхів та стратегій для фрормування висококваліфікованої робочої сили, зменшення обсягів відтоку фрахівців, тобто створення якісного людського капіталу в посткризисний період. Ключова задача, яка стоїть перед Україною - це перехід від переважно експортно-сир'яного до інвестиційно-інноваційного типу економічного розвитку, нарощування конкурентного української людського капіталу на основі реалізації національних стратегій в сфрері науки, освіти та високих технологій.

\section{Література:}

1. Світовий економічний форум. 2019. Звіт глобальної конкурентоспроможності. URL: http://www3.weforum.org/docs/WEF_TheGlobalCompetitivenessReport2019.pdf (дата звернення: 19.09.2020).

2. Всесвітній Економічний Форум. 2018. Звіт з глобальної конкурентоспроможності. URL: https:// www.weforum.org/reports/the-global-competitivenessreport-2017-2018 (дата звернення: 19.09.2020).

3. Світовий Економічний Форум. 2018. Індекс людського капіталу. 2018. URL: http://www3.weforum.org/ docs/HCR2016_Main_Report.pdf (дата звернення: 19.01.2021).
4. Міністерство Фінансів України. 2020. Видатки держбюджету України. URL: https://index.minfin.com.ua/ua/finance/budget/gov/expense/2020/ (дата звернення: 21.01.2021).

5. Про Державний бюджет України на 2018 рік: Закон України від 07 грудня 2017 р. № 2246-19. Відомості Верховної Ради України. 2018. № 3-4. Ст. 26.

6. Про Державний бюджет України на 2018 рік: Висновок на проєкт Закону України. URL: http:// w1.c1.rada.gov.ua/pls/zweb2/webproc4_1?pf3511=62551 (дата звернення: 15.11.2020).

7. Бережний В. М., Кравчук Ю. Б., Овсієнко К. І. Розвиток людського капіталу. 2011. URL: http:/ / nauka.kushnir.mk.ua/?p=29598 (дата звернення: 9.02.2021).

8. Фитценц Я. Рентабельность инвестиций в персонал: измерение экономической ценности персонала. 2006. 320 c.

9. Чухно А.А., Юхименко П.І., Леоненко П.М. Сучасні економічні теорії. 2007. 878 с.

10. Фінанси.ЮА. Еміграційні трагедії: досвід Польщі, Латвії та Румунії. 2017. URL: https://news.finance.ua/ua/news/-/393803/emigratsijni-tragediyi-dosvidpolshhi-latviyi-ta-rumuniyi (дата звернення: 9.02.2021).

\section{References:}

1. Schwab, K. (2019), "Global Competitiveness Report", available at: http://www3.weforum.org/docs / WEF_TheGlobalCompetitivenessReport2019.pdf (Accessed 10 Feb 2021).

2. World Economic Forum (2018), "Global Competitiveness Report", available at: https://www.weforum.org/reports/the-global-competitiveness-report20162017-1 (Accessed 10 Feb 2021).

3. World Economic Forum (2018), "The Human Capital Report", available at: http://www3.weforum.org/docs / HCR2016_Main_Report.pdf (Accessed 10 Feb 2021).

4. Ministry of Finance of Ukraine (2020), "Expenditures of the state budget of Ukraine", available at: https:// index.minfin.com.ua/ua/finance/budget/gov/ expense/2020/(Accessed 10 Feb 2021).

5. Verkhovna Rada of Ukraine (2018), The Law of Ukraine "On the State Budget of Ukraine for 2018", Vidomosti Verkhovnoi Rady Ukrainy, vol. 3-4, pp. 26.

6. Verkhovna Rada of Ukraine (2017), "On the State Budget of Ukraine for 2018: Opinion on the draft Law of Ukraine", available at: http://w1.c1.rada.gov.ua/pls/zweb2/ webproc4_1?pf3511=62551 (Accessed 10Feb 2021).

7. Beregnyi, V. Kravchuk, U. and Ovsienko K. (2011), "Development of human capital", available at: http:// nauka.kushnir.mk.ua/?p=29598 (Accessed 10 Feb 2021).

8. Fitcentc, Y. (2006), Rentabelnyst investicyi v personal: izmenenye ekonomicheskoi cennosti personala [Return on investment in personal: measuring the economic value of personal], Vershina, Moscow, Russia.

9. Chukhno, A. Ukhimenko, P. and Leonenko, P. (2007), Suchasni ekonomichny teorii [Modern economic theories], Znannya, Kyiv, Ukraine.

10. Finansy.UA (2017), "Emigration tragedies: the experience of Poland, Latvia and Romania", available at: https:/ / news.finance.ua/ua/news/-/393803/emigratsijni-tragediyidosvid-polshhi-latviyi-ta-rumuniyi (Accessed 10 Feb 2021). Стаття надійшла до редакиї 16.02.2021 p. 